\title{
SELECTIVE TENSE DEFICIT IN HUNGARIAN AGRAMMATIC APHASIA
}

\author{
ÉVA MÉSZÁROS
}

\author{
Research Institute for Linguistics \\ Hungarian Academy of Sciences \\ Benczúr u. 33. \\ H-1068 Budapest \\ Hungary \\ meva@nytud.hu
}

\begin{abstract}
The selective deficit of tense processing has recently become one of the phenomena most often examined by aphasiologists. It has repeatedly been shown that agrammatic aphasics have serious problems with the agreement of the time adverb and the tense morpheme, as opposed to the intactness of subject-verb agreement.

Nine Hungarian patients with agrammatic Broca's aphasia and nine healthy speakers participated in a study of sentence grammaticality judgement. Experiment 1, designed to measure ability to detect morphosyntactic violations (subject-verb agreement), included 40 ill-formed sentences containing an error of number. Ability to detect morphosemantic violation was tested in Experiment 2 including 80 ungrammatical sentences, where there was an incongruence between the time expressed by a time adverb (today, yesterday, tomorrow) and the tense of the verb. Our results indicate that Hungarian agrammatic aphasics show a selective deficit of tense, and that the position of an adverb influences sentence processing. These findings are discussed in a syntax-discourse model, which accounts not only for the selective deficit of tense, but also for the differences in working memory load necessary for the processing of sentences containing either a pre-verbal or a post-verbal time adverb.
\end{abstract}

Keywords: agrammatic aphasia, agreement, time-incongruence

\section{Introduction}

Agrammatism is characterized by an inability to produce grammatical syntactic structures, with a tendency toward substitution or omission of grammatical morphemes (case markers, agreement and tense verb inflection, function words) in speech. Sentences of agrammatic Broca's aphasics 
are described as non-fluent, fragmented and structurally simplified minimal phrases. Case assignment and verb inflection are also impaired. They often omit or substitute function words (prepositions, determiners). These symptoms are manifest in sentence processing, too.

Hungarian, as a richly inflected language, is especially suitable for studying inflectional errors in individuals with aphasia. In Hungarian, syntactic functions (i.e., subject, object, indirect object) are expressed by case suffixes attached to DPs and not by word order as in strictly configurational languages (like English). The agreement suffix appearing on the verb expresses the number and person of the subject, and these inflexional suffixes mark the agreement between the verb and the object, too. There are two verbal agreement paradigms ('indefinite' and 'definite'). Definiteness and/or specificity of the object determines which paradigm is used in a sentence containing a transitive verb. Table 1 summarizes the two inflectional paradigms of the verb kap 'receive, get' in the present tense.

Table 1

The two inflectional paradigms of the verb kap

\begin{tabular}{lll}
\hline $\begin{array}{l}\text { kap 'receive' } \\
\text { (by person and number) }\end{array}$ & $\begin{array}{l}\text { Indefinite } \\
\text { paradigm }\end{array}$ & $\begin{array}{l}\text { Definite } \\
\text { paradigm }\end{array}$ \\
\hline $1 \mathrm{sg}$ & kap +ok & $\mathrm{kap}+\mathrm{om}$ \\
$2 \mathrm{sg}$ & $\mathrm{kap}+\mathrm{sz}$ & $\mathrm{kap}+\mathrm{od}$ \\
$3 \mathrm{sg}$ & $\mathrm{kap}$ & $\mathrm{kap}+\mathrm{ja}$ \\
$1 \mathrm{pl}$ & $\mathrm{kap}+\mathrm{unk}$ & $\mathrm{kap}+\mathrm{juk}$ \\
$2 \mathrm{pl}$ & $\mathrm{kap}+\mathrm{tok}$ & $\mathrm{kap}+$ játok \\
$3 \mathrm{pl}$ & $\mathrm{kap}+$ nak & $\mathrm{kap}+$ ják \\
\hline
\end{tabular}

It is well known that the time structure of a situation can be represented by the relationship of speech time, event time and reference time (Reichenbach 1947; Comrie 1985). Speech time refers to the 'moment of speech' and event time to the time of a situation expressed by the sentence. Reference time is the time to which the event time is related. Tenses are grammaticalised expressions of the relation between three temporal primitives along the time-axis. Thus, event time can precede, follow or coincide with the speech time, denoting simple past, future and present tenses respectively. These three basic tenses are absolute tenses, in the sense that they directly relate the event time to the speech time ('here and now'). Relative tenses, in contrast, take a time interval other than speech time as a reference point. For example, in (1) the reference point 
(reference time) for the event of John's leaving is the event time of the second situation, the police arriving.

(1) John had left the house before the police arrived.

The tense and a "frame" time adverb identifies the external time structure of a sentence. (Internal time structure concerns the inner chronology or aspect of a situation.) The so called "frame" time adverbs tegnap 'yesterday', ma 'today', holnap 'tomorrow' do not specify the event time as a single/definite point, but refer to an interval. These adverbs are instances of absolute time reference, in the sense that they consider the speech time as the reference point (Comrie 1985). Thus, the adverb ma 'today', the so-called "extended present", locates the situation within the day that includes the present moment. The adverb tegnap 'yesterday' specifies an interval that precedes the current day, and the adverb holnap 'tomorrow' refers to the day following the current day (ibid.).

In simple sentences (containing simple past, present, future tenses), the function of a frame time adverb is to specify the event time denoted by a tense morpheme. Morphological time (indicated by null suffix in present, and $-t / t t$ in past tense) has to agree with semantic time (designated by a "frame" time adverb). The agreement between them is manifested through a morphosemantic process. Table 2 summarizes the frame time adverbs together with the tense morphemes allowed in simple sentences.

\section{Table 2}

The frame time adverbs and the verbal tense morphemes permitted in simple sentences

\begin{tabular}{ll}
\hline Frame time adverb & Permitted tense morphology \\
\hline tegnap 'yesterday' & $\begin{array}{l}\text { past tense }(-t / t t) \\
\text { present tense (null suffix) only in special register }\end{array}$ \\
\hline$m a$ 'today' & $\begin{array}{l}\text { past tense }(-t / t t) \\
\text { present tense (null suffix) } \\
\text { future tense (auxiliary fog) }\end{array}$ \\
\hline holnap 'tomorrow' & $\begin{array}{l}\text { present tense (null suffix) } \\
\text { future tense (auxiliary fog) }\end{array}$ \\
\hline
\end{tabular}

The ability of individuals with Broca's aphasia to process tense and agreement markers has been widely tested in diverse languages. A number 
of experiments indicate that patients with agrammatic aphasia produce verbs with the suitable person and number in a larger proportion than with the suitable tense (Friedmann-Grodzinsky 1997; Hagiwara 1995; Wenzlaff-Clahsen 2004; Clahsen-Ali 2009). The selective deficit of tense, however, is not only manifest in sentence production experiments but was also observed in grammaticality judgement tasks (Dickey et al. 2005; Nanousi et al. 2006; Varlokosta et al. 2006; Wenzlaff-Clahsen 2004). In these studies patients performed better at judging sentences with agreement errors (2) than at judging ones containing a tense-time adverb incongruence (3).

(2) *The boy are walking.

(3) *The boy is walking yesterday.

There is no consensus among researchers about either the existence of the tense deficit, or about the nature of the impairment behind it.

Nowadays the Tree Pruning Hypothesis (TPH, Friedmann-Grodzinsky $1997 ; 2000)$, based on the principles and the modules of generative grammar (Minimalist Program (MP), Chomsky 1995), is one of the most often used models for the interpretation of tense deficits. In accordance with the MP, sentence structure is represented as projections of lexical and functional categories, which are organized hierarchically. The functional projection TenseP is responsible for the tense inflection of the verb. AgrsP is responsible for the agreement of number and person between the verb and the subject. According to the Tree Pruning Hypothesis (TPH) (Friedmann-Grodzinsky 1997; 2000), the higher a functional node is the more vulnerable it is in syntactic representation in agrammatic aphasia (Figure 1). That is, the lower the "pruning", the smaller the number of unimpaired functional projections in the syntactic structure.

If there is a selective deficit of tense, the tree is pruned between TenseP and AgrsP. As a consequence, the functional projection TenseP and those that are located higher in the syntactic structure are underspecified, while AgrsP remains intact. From a sentence comprehension point of view this means that processing of the tense morpheme is impaired, but processing of the person and the number inflectional morphemes are intact.

The postulation of the tree-pruning hypothesis was motivated by a Hebrew agrammatic patient. In Hebrew the TenseP is higher up in the syntactic tree than AgrsP is. However, there are languages in which the 


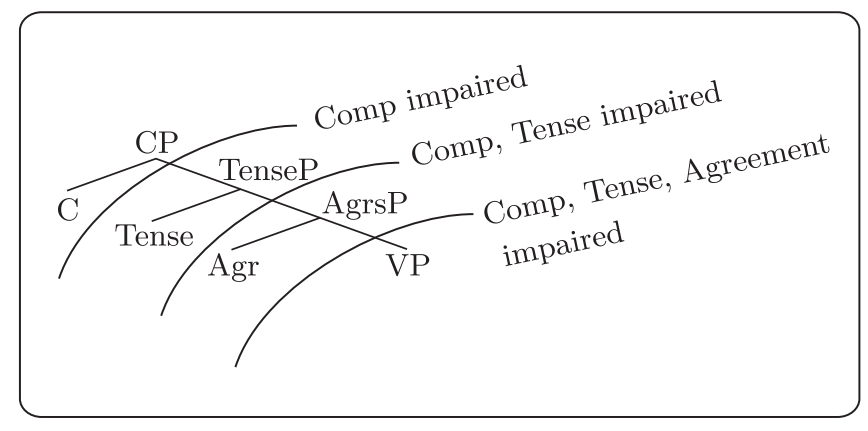

Fig. 1

According to the Tree Pruning Hypothesis (Friedmann-Grodzinsky 1997), the underspecified node and those that are above it are impaired in an agrammatic syntactic structure. For example, the CP node is only impaired in case of mild agrammatism. However, both AgrsP and TenseP nodes can be damaged in severe forms of agrammatism.

ordering of TenseP and AgrsP in the syntactic tree is reversed. Thus, the $\mathrm{TPH}$ predicts that in these languages agreement is more vulnerable than tense.

Wenzlaff and Clahsen (2004) examined the processing of tense and agreement in a grammaticality judgement task in German agrammatic aphasics. According to the Tense-Agr Underspecification Hypothesis (TAUH) of the authors, the TenseP is an inflectional complex that contains not only the tense feature, but mood and agreement features as well (Figure 2).

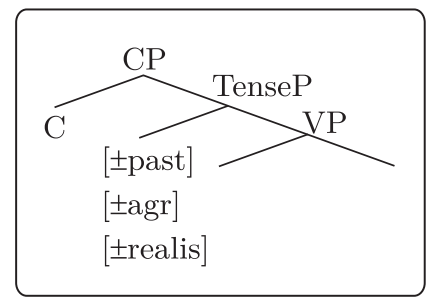

Fig. 2

The Tense-Agr Underspecification Hypothesis (TAUH, Wenzlaff-Clahsen 2004) assumes that the mood feature [realis] and the agreement feature [agr] are specified, but the tense feature [tense] is underspecified in an ungrammatical syntactic representation of the sentence

The selective impairment of tense results from the underspecification of the tense feature itself while other features (agreement, mood) remain 
intact. One of the consequences of this is that the patients show no sensitivity to the difference between 'past tense-not past tense'.

Faroqi-Shah and Thompson (DER, Diacritical feature Encoding and Retrieval, 2007) claimed that the locus of the tense deficit is a failure of morphosemantic - and not purely morphosyntactic - processes. Following Levelt (1989), they suppose that various aspects of a speaker's message (temporal reference, aspect) are represented by diacritical features on a conceptual level ([ \pm PAST $]$ for tense, and [ \pm PROGRESSIVE] for mood). Morphosemantic processes translate these features into specific morphological forms. Processing a diacritical feature and utilizing this information to select a tense suffix are indispensable to accomplish the time structure of a sentence. For example, in a situation The cat chased a mouse the diacritical feature [+PAST] guides the selection of a matching tense suffix $-d$. The tense deficit is specific to encoding a diacritical feature resulting in impaired processing of the tense morpheme during sentence comprehension.

The position of the time adverb (pre-posed or post-posed) has a significant effect on sentence processing (Faroqi-Shah-Dickey 2009). Results of an online grammaticality judgement task indicated that patients were less accurate and slower in their judgement of sentences containing preposed time adverbs (Next year, my sister lived in New Hampshire) than sentences containing a post-posed one (My sister lived in New Hampshire next year). Faroqi-Shah and Dickey (2009) emphasized that the deficit was more specific. They attributed this asymmetry to the inability of aphasics to select the tense morpheme based on conceptual semantic time information (expressed by the time adverb). This selection deficit has an effect only on sentences containing pre-posed time adverbs, since the correct tense morpheme has to be selected on the basis of the time adverb (conceptual-semantic time information) in these sentences. In the sentences involving post-posed time adverbs, the tense morpheme is given before encountering the sentence final adverb, so morpheme selection is not required.

Unfortunately, Faroqi-Shah and Dickey (2009) do not provide an exhaustive explanation either for the role of morpheme selection or for the asymmetry. They propose that the processing of tense morphemes itself is not damaged, and the deficit only affects the translation of conceptual-semantic information into tense morphology. This would explain the observation that the sentence initial time adverb does not elicit faster processing of the tense morpheme, resulting in slow reaction times. 
However, it is not clear why the rate of correct decisions decreased in these sentences, since the tense morpheme is present in all sentences, and its interpretation is unimpaired. Presumably, the morpheme selection deficit affects sentence production tasks (i.e., forced-choice sentence completion task, picture description) more than it affects grammaticality judgement tasks.

Several studies emphasize the anaphoric nature of tense interpretation, i.e., that the event time (or reference time) of a sentence depends on the time structure of the preceding sentence (Giorgi-Pianesi 1997; Partee 1973). Given this property, tense deficit can be conceived of as an impairment at the syntax-semantics interface level.

Avrutin (2006) connects agreement and tense processing to two different linguistic levels of sentence processing. The three fundamental ideas of his syntax-discourse theory are: (i) an economy hierarchy of structure building operations (Reuland 2001), that means the fewer memory resources a syntactic/semantic operation needs the more economical it is for working memory, (ii) an effect of non-linguistic context on sentence interpretation, and (iii) pathologically restricted working memory capacity in agrammatic aphasics. There are various types of dependency relations between the elements of a sentence. A syntactic dependence exists between the subject and the verb, and between the possessor and the possessed. Semantic dependence characterizes the relation between the pronoun and its reference. The identification of the dependent elements within and between the sentences carries different computation loads, depending on which linguistic module's/modules' operation(s) is/are required. Morphosyntactic structure building processes connected to narrow syntax are the "cheapest", and operations associated with the linguistic-discourse level involve the highest computation load (Figure 3, overleaf).

The problem with this theory from the point of view of the interpretation of our results is that it cannot account for the asymmetry found between pre-posed and post-posed time adverbs. It only takes the economy hierarchy of structure building operations into consideration, but it pays no attention to factors that might be relevant for sentence processing (i.e., word order, structural preference/structural expectance during sentence processing). These factors, however, can make sentence processing more costly, resulting in an inability to correctly comprehend sentences in individuals with agrammatic Broca's aphasia.

The first purpose of the current study was to investigate morphosyntactic and morphosemantic processing in Hungarian agrammatic apha- 


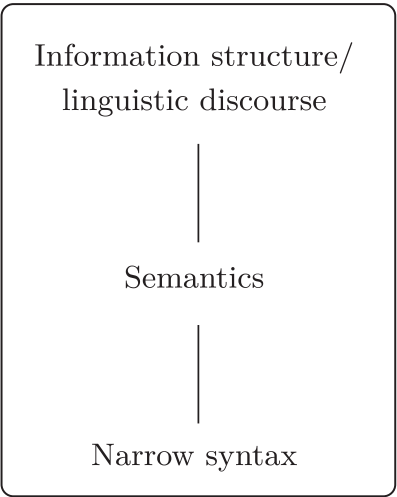

Fig. 3

The linguistic levels of the syntax-discourse model (based on Avrutin 2006)

sics, in order to reveal any possible dissociation between the processing of tense and agreement in Hungarian aphasics. The second purpose was to examine whether the position of the time adverb has an effect on sentence processing. These questions were addressed in two grammaticality judgement tasks, where scores and mean reaction times were analysed.

We assumed that if the TPH (Friedmann-Grodzinsky 1997) applies to Hungarian sentences, the detection of an adverb-verb violation is more impaired, and takes more time than the detection of a subjectverb violation. A syntax-discourse model, in contrast, predicts either more impaired agreement, or impairments for both tasks. As for word order asymmetry, two theories make different predictions. DER (FaroqiShah-Thompson 2007) predicts lower accuracy and higher reaction time for judgement of sentences containing a pre-posed time adverb. Syntaxdiscourse theory, however, predicts no difference between sentences containing either a pre-posed or a post-posed adverb.

\section{Participants}

Nine patients with agrammatic aphasia took part in the study. According to scores on the Hungarian version of the Western Aphasia Battery (adapted by Osmanné Sági 1991), they all fit the pattern of Broca's aphasia. Nine age matched, neurologically intact participants represented the control group. Tables 3 and 4 show personal and clinical data of participants with and without aphasia. 
Table 3

Clinical and personal data of aphasic participants

\begin{tabular}{|c|c|c|c|c|c|c|c|}
\hline Subject & Gender & Age & $\begin{array}{l}\text { Education } \\
\text { (years) }\end{array}$ & $\begin{array}{l}\text { Post onset } \\
\text { (month) }\end{array}$ & $\begin{array}{l}\text { CT-lesion } \\
\text { site }\end{array}$ & $\begin{array}{l}\text { WAB } \\
\text { scores }\end{array}$ & $\begin{array}{l}\text { Taken } \\
\text { scores }\end{array}$ \\
\hline$\overline{\mathrm{VL}}$ & $\bar{M}$ & 51 & 12 & 24 & left fronto-temporal & $\begin{array}{l}\text { Broca } \\
\text { (AQ:53) }\end{array}$ & 3 \\
\hline $\mathrm{BK}$ & M & 60 & 16 & 6 & left fronto-temporal & $\begin{array}{l}\text { Broca } \\
\text { (AQ: 59) }\end{array}$ & 26.5 \\
\hline PGY & M & 40 & 12 & 8 & left $\mathrm{ACM}$ area & $\begin{array}{l}\text { Broca } \\
\text { (AQ: 20.0) }\end{array}$ & 9 \\
\hline $\mathrm{BA}$ & M & 40 & 12 & 24 & left $\mathrm{ACM}$ area & $\begin{array}{l}\text { Broca } \\
\text { (AQ: 26.5) }\end{array}$ & 8 \\
\hline VI & M & 45 & 16 & 8 & left ACA area & $\begin{array}{l}\text { Broca } \\
\text { (AQ: 15.8) }\end{array}$ & 10 \\
\hline NyI & M & 60 & 8 & 12 & left fronto-temporal & $\begin{array}{l}\text { Broca } \\
\text { (AQ: 60.4) }\end{array}$ & 25 \\
\hline SJ & $\mathrm{F}$ & 51 & 12 & 6 & left fronto-temporal & $\begin{array}{l}\text { Broca } \\
\text { (AQ: } 30.8 \text { ) }\end{array}$ & 13 \\
\hline $\mathrm{PM}$ & $\mathrm{F}$ & 57 & 17 & 3 & $\begin{array}{l}\text { left fronto-temporal- } \\
\text { parietal }\end{array}$ & $\begin{array}{l}\text { Broca } \\
\text { (AQ: 15) }\end{array}$ & 15 \\
\hline VT & $\mathrm{F}$ & 39 & 12 & 12 & $\begin{array}{l}\text { left fronto-temporal- } \\
\text { parietal }\end{array}$ & $\begin{array}{l}\text { Broca } \\
\text { (AQ: } 45.8 \text { ) }\end{array}$ & 19 \\
\hline
\end{tabular}

Table 4

Data of participants in the control group

\begin{tabular}{cccc}
\hline Participant & Gender & Age & $\begin{array}{c}\text { Education } \\
\text { (years) }\end{array}$ \\
\hline C1 & M & 52 & 16 \\
C2 & M & 40 & 11 \\
C3 & M & 56 & 12 \\
C4 & F & 55 & 12 \\
C5 & F & 52 & 16 \\
C6 & F & 57 & 16 \\
C7 & F & 45 & 16 \\
C8 & M & 34 & 18 \\
C9 & F & 31 & 15 \\
\hline
\end{tabular}




\section{Experiment 1: judgement of agreement}

\subsection{Materials}

Experiment 1 was designed to test sensitivity to agreement in 40 SOV (subject-object-verb) and 40 VOS (verb-object-subject) target sentences and 80 fillers. Within each of the two word order types, there were 20 grammatical and 20 ungrammatical sentences. Ungrammaticality was caused by a mismatch between the agreement features of the subject and the verb. In all sentences the subjects and the objects were expressed by definite DPs. The verb form was third person singular (3sg) in grammatical and third person plural (3pl) in ungrammatical sentences. Examples are given in (4) below.

(4) (a) SOV grammatical sentence $(n=20)$ :

A lány a verset megtanulja. $\#^{1}$

the girl-3sg the poem-acc learn-pres.3sg

'The girl learns the poem.'

(b) SOV ungrammatical sentence $(n=20)$ :

*A lány a verset megtanulják. \#

the girl-3sg the poem-acc learn-pres.3pl

'*The girl learn the poem.'

(c) VOS grammatical sentence $(n=20)$ :

Megtanulja a verset a lány. \# learn-pres.3sg the poem-acc the girl-3sg

'The girl learns the poem.'

(d) VOS ungrammatical sentence $(n=20)$ :

*Megtanulják a verset a lány. \# learn-pres.3pl the poem-acc. the girl-3sg

'*The girl learn the poem.'

\subsection{Procedure}

Experimental sentences were recorded. They were pronounced with natural intonation and normal rate of speech. Participants were tested individually in a room free of distraction. They had to make a decision on

${ }^{1}$ \# marks the beginning of the measure of reaction time. 
the grammatical correctness of the sentences heard through a headphone. They were asked to press a key if the sentence they heard was grammatical (the "space" key in the keyboard coded with green) and to press a different key if the sentence was ungrammatical (the "enter" key coded by red). Participants were asked to respond as accurately and quickly as they could. Repetition of the target sentences was not possible. The reaction time (or decision time), i.e., the time interval between the offset of the target sentence and the beginning of the response, was registered by a computer program (programmed in Delphi 6 by Bertalan Dankó). We assessed the number of correct decisions and reaction times.

\subsection{Results}

Accuracy. The rate of correct decisions was at "ceiling" level in control participants, and above chance in aphasics in almost all sentence types (see Table 5). The two groups' mean accuracy scores were compared in an overall analysis of variance (ANOVA) with word order and grammaticality as within-subject factors, and group as a betweensubject factor. The analysis revealed a significant main effect of group $(F(1,16)=8.502, p<0.001)$, aphasics being less accurate with all sentence types than control participants. We did not find a significant main effect either for word order $(F(1,16)=0.084$, n.s. $)$ or for grammaticality $(F(1,16)=1.334$, n.s.), and no interactions were found between the factors (word order*group $F(1,16)=0.876$, n.s.; grammaticality $*$ group $F(1,16)=2.705$, n.s.; word order $*$ grammaticality $F(1,16)=0.700$, n.s.; word order $*$ grammaticality $*$ group $F(1,16)=0.383$, n.s.).

\section{Table 5}

Rate of correct decisions and mean reaction times in the judgement of agreement (standard deviation after "|")

\begin{tabular}{|c|c|c|c|c|c|c|c|c|}
\hline & & 6 of corre & t decisi & & & Mean reac & tion times & \\
\hline & & DV & & OS & & $\mathrm{V}$ & & $\mathrm{S}$ \\
\hline & Gram. & Ungram. & Gram. & Ungram. & Gram. & Ungram. & Gram. & Ungram. \\
\hline $\mathrm{CG}$ & $99 \mid 0.66$ & 100 & $98 \mid 1.50$ & $99 \mid 1.45$ & $565 \mid 164$ & $473 \mid 126$ & $519 \mid 196$ & $646 \mid 159$ \\
\hline$A G$ & $96 \mid 4.33$ & $93 \mid 7.07$ & $96 \mid 5.46$ & $95 \mid 6.12$ & $1400 \mid 720$ & $1266 \mid 354$ & $1653 \mid 923$ & $1416 \mid 417$ \\
\hline
\end{tabular}


Reaction times. The mean reaction times were compared in an overall analysis of variance with word order and grammaticality as within-subject factors, and group as a between-subject factor (see Table 5). The analysis revealed a significant main effects of group $(F(1,16)=22.675, p<0.001)$ and word order $(F(1,16)=5.266 p<0.05)$. Aphasic patients were slower than controls in all sentence types. There was no evidence of a grammaticality effect $(F(1,16)=0.742$, n.s. $)$ or of the interaction of word order, grammaticality and group (word order*group $F(1,16)=1.427$, n.s.; grammaticality $*$ group $F(1,16)=1.074$, n.s.; word order*grammaticality $F(1,16)=0.400$, n.s.; word order $*$ grammaticality $*$ group $F(1,16)=$ 3.030 , n.s.). Further analyses of variance on reaction times was carried out for each group separately in order to make clear the effect of word order within the groups.

In the aphasic group we did not find any effect for word order $(F(1,8)=3.077$, n.s. $)$ or grammaticality $(F(1,8)=0.908$, n.s. $)$, and there was no interaction between the two factors (word order*grammaticality $F(1,8)=0.311$, n.s. $)$.

In the control group, in contrast, a significant main effect for word order, and an interaction between word order and grammaticality was found (word order $F(1,8)=28.472, p<0.01$; grammaticality $F(1,8)=0.859$, n.s.; word order $*$ grammaticality $F(1,8)=100.341, p<0.001)$. The reaction times of ungrammatical and grammatical sentences showed opposite patterns in the two word orders. A paired samples $t$-test revealed that for the SOV sentences the mean reaction times for the grammatical sentences were significantly higher than for the ungrammatical ones $(t(8)=4.121, p<0.01)$. For VOS sentences, in contrast, the mean reaction times for the grammatical sentences were significantly lower than for the ungrammatical ones $(t(8)=-6.177, p<0.001)$. This dissociation was a characteristic feature of the performance of the control group. At the individual level, however, the group pattern of reaction times was found only in one out of nine control participants (see the Appendix). Three (out of nine) control participants judged grammatical sentences more slowly than ungrammatical ones in SOV order, however, in VOS order there was no significantly reliable difference between grammatical and ungrammatical sentences. In four of the nine control subjects there was no significant difference between reaction times for grammatical and ungrammatical sentences in SOV word order. In VOS order, however, mean reaction times were slower for ungrammatical sentences than for 
grammatical ones. In one control subject no interaction between word order and grammaticality was found on reaction times.

To summarize, the results of Experiment 1 showed that aphasic patients judged sentences more slowly than control subjects, though they performed at a very high level of accuracy. Sentence grammaticality and word order did not influence their performance. In order to compare the effects of morphosyntactic and morphosemantic factors on aphasic sentence processing, a further grammaticality judgement task containing sentences with a mismatch between a verb and a time adverb was administered.

\section{Experiment 2: judgement of tense violation}

\subsection{Materials}

160 grammatical and 80 ungrammatical sentences were collected to measure sensitivity to time-incongruency in aphasic and healthy participants. Ungrammaticality was caused by the incongruence of the tense expressed by verbal morphology and of the time expressed by the time adverb present in the sentence. Two word order variations were tested:

1. Sentences with a preverbal time adverb: subject-time adverb-objectverb (hereafter referred to as SAdvOV)

2. Sentences with a postverbal time adverb: subject-verb-object-time adverb (hereafter referred to as SVOAdv)

All target sentences contained verb forms in present or past tense in definite conjugation. The subjects and the objects were expressed by definite DPs. Sentences contained one of the frame time adverbs (today/yesterday/tomorrow). Table 6 presents task structure and examples of stimuli.

\subsection{Procedure}

Participants and procedure were the same as in Experiment 1. 


\section{Table 6}

Types of SAdvOV and SVOAdv target sentences

("*" marks ungrammatical sentences; pres $=$ present tense)

\begin{tabular}{|c|c|c|}
\hline Sentence type & $\begin{array}{l}\text { Pre-verbal time adverb } \\
\text { SAdvOV }(n=120)\end{array}$ & $\begin{array}{l}\text { Post-verbal time adverb } \\
\text { SVOAdv }(n=120)\end{array}$ \\
\hline $\begin{array}{l}\text { [today-Vpast] } \\
(n=20)\end{array}$ & $\begin{array}{l}\text { A kislány ma a feladatot megcsinálta. } \\
\text { 'The girl today the task performed.' }\end{array}$ & $\begin{array}{l}\text { A kislány megcsinálta a feladatot ma. } \\
\text { 'The girl performed the task today.' }\end{array}$ \\
\hline $\begin{array}{l}\text { [today-Vpres] } \\
(n=20)\end{array}$ & $\begin{array}{l}\text { A kislány ma a feladatot megcsinálja. } \\
\text { 'The girl today the task performs.' }\end{array}$ & $\begin{array}{l}\text { A kislány megcsinálja a feladatot ma. } \\
\text { 'The girl performs the task today.' }\end{array}$ \\
\hline $\begin{array}{l}\text { [yesterday-Vpast] } \\
(n=20)\end{array}$ & $\begin{array}{l}\text { A kislány tegnap a feladatot meg- } \\
\text { csinálta. 'The girl yesterday the task } \\
\text { performed.' }\end{array}$ & $\begin{array}{l}\text { A kislány megcsinálta a feladatot } \\
\text { tegnap. 'The girl performed the task } \\
\text { yesterday.' }\end{array}$ \\
\hline $\begin{array}{l}*[\text { yesterday-Vpres }] \\
(n=20)\end{array}$ & $\begin{array}{l}\text { *A kislány tegnap a feladatot meg- } \\
\text { csinálja. 'The girl yesterday the task } \\
\text { performs.' }\end{array}$ & $\begin{array}{l}\text { *A kislány megcsinálja a feladatot } \\
\text { tegnap. 'The girl performs the task } \\
\text { yesterday.' }\end{array}$ \\
\hline $\begin{array}{l}*[\text { tomorrow-Vpast }] \\
(n=20)\end{array}$ & $\begin{array}{l}\text { *A kislány holnap a feladatot meg- } \\
\text { csinálta. 'The girl tomorrow the task } \\
\text { performed.' }\end{array}$ & $\begin{array}{l}\text { *A kislány megcsinálta a feladatot } \\
\text { holnap. 'The girl performed the task } \\
\text { tomorrow.' }\end{array}$ \\
\hline $\begin{array}{l}\text { [tomorrow-Vpres] } \\
(n=20)\end{array}$ & $\begin{array}{l}\text { A kislány holnap a feladatot meg- } \\
\text { csinálja. 'The girl tomorrow the task } \\
\text { performs.' }\end{array}$ & $\begin{array}{l}\text { A kislány megcsinálja a feladatot } \\
\text { holnap. 'The girl performs the task } \\
\text { tomorrow.' }\end{array}$ \\
\hline
\end{tabular}

\subsection{Results}

Accuracy. To control for the possibility that aphasic subjects might be biased toward accepting ungrammatical sentences as grammatical, we calculated $\mathrm{A}^{\prime}$-scores for each aphasic participant and for the aphasic group. $\mathrm{A}^{\prime}$ is a so-called discrimination index, which can be interpreted as a measure for sensitivity to sentence grammaticality (Linebarger et al. 1983).

Following Rice et al. (1999), we supposed that perfect discrimination (accepting grammatical sentences and rejecting ungrammatical sentences) yields an $\mathrm{A}^{\prime}$ of 1.00. A chance performance yields an $\mathrm{A}^{\prime}$ of 0.50 . An $A^{\prime}$ value of less than 0.50 shows a tendency to reject all sentences. In the aphasic group examined, the range of corrected scores $\left(\mathrm{A}^{\prime}\right)$ for ungrammatical sentences was $71 \%-80 \%$, indicating a diminished sensitivity to the well-formedness of sentences (Figure 4). A'-corrected scores confirmed that aphasic participants did not show a preference for accepting or rejecting ungrammatical sentences.

An overall analysis of variance (ANOVA) on $\mathrm{A}^{\prime}$-corrected scores revealed a significant main effect of group $(F(1,16)=28.68, p<0.001)$. We did not find significant effects of word order and grammaticality, however, 


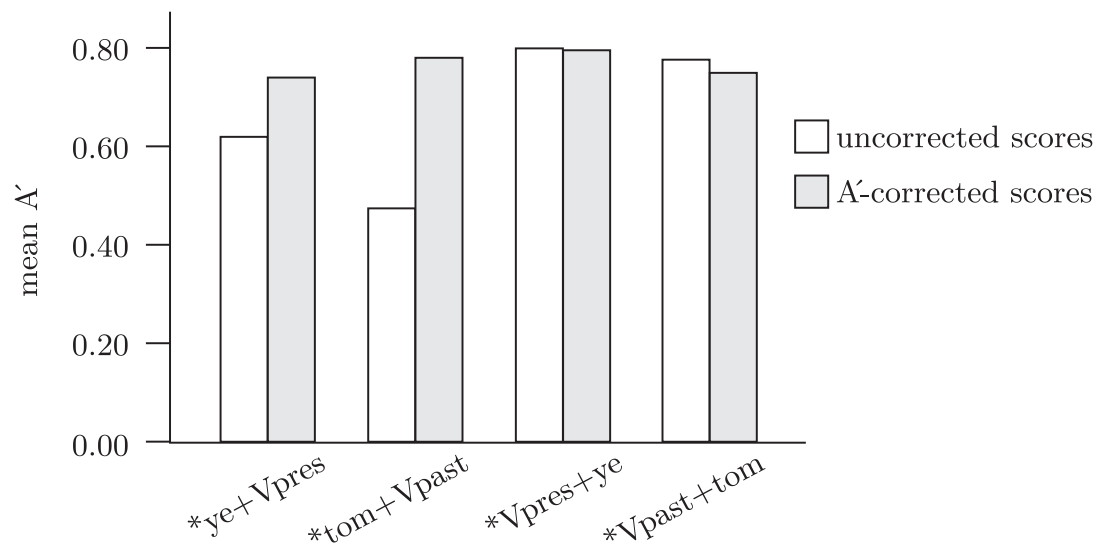

Fig. 4

Corrected $\mathrm{A}^{\prime}$-scores of the ungrammatical sentences

their interaction with group was significant (word order: $F(1,16)=4.138$, n.s.; grammaticality: $F(1,16)=0.837$, n.s.; word order $*$ grammaticality* group: $F(1,16)=21.75, p<0.001)$.

Table 7

Accuracy and reaction times in the control and aphasic groups

\begin{tabular}{lccccc}
\hline & \multicolumn{2}{c}{ \% of correct decisions } & & \multicolumn{2}{c}{ Mean reaction times (ms) } \\
\cline { 2 - 3 } \cline { 5 - 6 } & Control & Aphasic & & Control & Aphasic \\
\hline Preverbal adverb & & & & & \\
today+Vpast & 98 & 89 & & 591 & 1376 \\
today+Vpresent & 99 & 90 & & 542 & 1168 \\
yesterday+Vpast & 99 & 88 & & 432 & 1318 \\
*yesterday+Vpresent & 98 & 71 & & 729 & 2075 \\
*tomorrow+Vpast & 99 & 78 & & 738 & 2000 \\
tomorrow+Vpresent & 99 & 87 & & 513 & 1613 \\
Mean & $\mathbf{9 9}$ & $\mathbf{8 2}$ & & $\mathbf{5 9 1}$ & $\mathbf{1 5 9 2}$ \\
\hline Postverbal adverb & & & & \\
Vpast+today & 99 & 86 & & 620 & 1741 \\
Vpresent+today & 100 & 89 & & 606 & 1587 \\
Vpast+yesterday & 96 & 59 & & 521 & 1501 \\
* Vpresent+yesterday & 99 & 80 & & 497 & 1426 \\
*Vpast+tomorrow & 99 & 75 & & 515 & 1525 \\
Vpresent+tomorrow & 98 & 58 & & 483 & 1432 \\
Mean & $\mathbf{9 9}$ & $\mathbf{7 4}$ & & $\mathbf{5 4 0}$ & $\mathbf{1 5 3 5}$ \\
\hline
\end{tabular}


A separate variance analysis on the accuracy scores of the aphasic and the control group was conducted to get a clear picture about the interaction between word order and grammaticality within the two groups. In the control group no effect of word order, grammaticality or their interaction was found (word order $F(1,8)=1.00$, n.s.; grammaticality $F(1,8)=$ 0.151 , n.s.; word order*grammaticality $F(1.8)=1.969$, n.s.). The rate of correct decisions was at "ceiling" level in case of both word orders regardless of the grammaticality of the sentences (Table 7).

In the aphasic group an interaction was found between word order and grammaticality (word order $F(1,8)=3.724$, n.s.; grammaticality $F(1,8)=0.730$, n.s.; word order $*$ grammaticality $F(1,8)=26.8, p<$ $0.01)$. A series of paired-sample $t$-tests was also carried out comparing the rate of grammatical and ungrammatical sentences within the two word orders (see Table 8.). In the SAdvOV word order, the percentages of correct decisions were significantly lower for ungrammatical sentences than for grammatical ones. In SVOAdv sentences, in contrast, the rate of correct decision was significantly higher for ungrammatical sentences than for grammatical ones.

Table 8

Results of $t$-test for the accuracy scores in the aphasic group

\begin{tabular}{llllll}
\hline & \multicolumn{2}{c}{ SAdvOV } & & \multicolumn{2}{c}{ SVOAdv } \\
\cline { 2 - 3 } \cline { 5 - 6 } Sentence type & *yest.-Vpres & *tom.-Vpast & & *yest.-Vpres & *tom.-Vpast \\
\hline yesterday-Vpast & $t(8)=2.532$ & $t(8)=2.492$ & & $t(8)=1.538$ & $t(8)=0.450$ \\
& $p<0.05$ & $p<0.05$ & n.s. & n.s. \\
tomorrow-Vpres & $t(8)=2.490$ & $t(8)=2.684$ & $t(8)=1.579$ & $t(8)=0.149$ \\
& $p<0.05$ & $p<0.05$ & n.s. & n.s. \\
\hline
\end{tabular}

Reaction times. An overall repeated measure analysis of variance (ANOVA) with word order, grammaticality, adverb types as within-subjects factors, and group as between-subjects factor, found a significant main effect of group and word order (group: $F(1,16)=24.120, p<0.001$; word order: $F(1,16)=11.160, p<0.01)$. Generally, patients with aphasia were slower than controls in both word orders. More importantly, there was a significant interaction of word order and grammaticality (word order: $F(1,16)=11.160, p<0.01$, grammaticality: $(F(1,16)=2.558$, n.s., word order*grammaticality: $F(1,16)=12.162, p<0.01)$. 
Comparing reaction times for grammatical and ungrammatical sentences revealed that in both groups the mean reaction times were significantly higher in ungrammatical sentences than in grammatical ones, but only in the SAdvOV word order. In the SVOAdv sentences, in contrast, no statistically significant difference was found between them (see Table 9).

Table 9

Results of $t$-test for mean reaction times in the two groups

\begin{tabular}{llllll}
\hline & \multicolumn{2}{c}{ SAdvOV } & & \multicolumn{2}{c}{ SVOAdv } \\
\cline { 2 - 3 } & *yest.-Vpres & *tom.-Vpast & & *yest.-Vpres & $*_{\text {tom.-Vpast }}$ \\
\hline Control group & & & & & \\
yesterday-Vpast & $t(8)=-9.831$ & $t(8)=5.921$ & & $t(8)=0.418$ & $t(8)=0.741$ \\
& $p<0.001$ & $p<0.001$ & & n.s. & n.s. \\
tomorrow-Vpres & $t(8)=-4.133$ & $t(8)=3.052$ & & $t(8)=-0.278$ & $t(8)=0.441$ \\
& $p<0.01$ & $p<0.05$ & & n.s. & n.s. \\
\hline Aphasic group & & & & \\
yesterday-Vpast & $t(8)=-3.083$ & $t(8)=2.633$ & & $t(8)=0.378$ & $t(8)=0.268$ \\
& $p<0.05$ & $p<0.05$ & & n.s. & n.s. \\
tomorrow-Vpres & $t(8)=1.283$ & $t(8)=-1.057$ & $t(8)=0.455$ & $t(8)=0.381$ \\
& $p<0.05$ & $p<0.05$ & n.s. & n.s. \\
\hline
\end{tabular}

Comparing the performance of the aphasic group across the two experiments, it is apparent that the rate of correct decisions is higher and the mean reaction time is lower in the agreement judgement task than in the time congruence task (see Table 10, overleaf). This pattern is in concert with previous observations in the literature (Friedmann-Grodzinsky 1997; Hagiwara 1995; Wenzlaff-Clahsen 2004; 2005).

\section{Discussion}

The aim of the present study was to investigate Broca's aphasics' ability to judge morphosyntactic and morhosemantic violations, and to examine the effect of time adverb position on grammaticality judgement. It is not surprising that tense processing is problematic for patients with agrammatic aphasia. However, there is little data in the literature on the 
Table 10

The rate of correct decisions and mean reaction times in the two experiments in the control and aphasic groups (standard deviation after "|")

\begin{tabular}{lccccc}
\hline & \multicolumn{2}{c}{$\%$ of correct decisions } & & \multicolumn{2}{c}{ Mean reaction times (ms) } \\
\cline { 2 - 3 } & Control & Aphasic & & Control & Aphasic \\
\hline $\begin{array}{l}\text { Experiment } 1 \\
\text { Agreement }\end{array}$ & $99 \mid 0.33$ & $97 \mid 4.132$ & & $551 \mid 159.5$ & $1434 \mid 595.3$ \\
\hline $\begin{array}{l}\text { Experiment } 2 \\
\text { Time congruence }\end{array}$ & $99 \mid 1.691$ & $79 \mid 5.24$ & & $566 \mid 174.2$ & $1564 \mid 684.5$ \\
\hline & $\begin{array}{c}t(8)=12.188 \\
\text { n.s. }\end{array}$ & $\begin{array}{c}t(8)=12.188 \\
p<0.001\end{array}$ & $\begin{array}{c}t(8)=-3.406 \\
p<0.05\end{array}$ & $\begin{array}{c}t(8)=-4.048 \\
p<0.01\end{array}$ \\
\hline
\end{tabular}

effect of the position of the time adverb on grammaticality judgements. In order to interpret our results, we were searching for a model that is able to account for the effect of word order and grammaticality at the same time.

Our first research question was whether the agreement-tense dissociation reported in several studies in diverse languages can also be found in Hungarian. Since our aphasic participants performed better in the judgement of agreement violation than they did in the judgement of tense incongruence, the answer is yes. Moreover, this performance, at first glance, fits in with the prediction of the Tree Pruning Hypothesis. We might say that only the TenseP (which is responsible for tense inflection) is damaged, but the AgrsP (which is responsible for number and person agreement) is not. In spite of this appealing conclusion, we think that our results do not support the validity of the TPH. This theory cannot adequately account for the selective deficit of tense in Hungarian for two reasons.

First, the functional projection TenseP, contrary to Hebrew, is in a lower position than AgrsP in the syntactic structure of Hungarian sentences (see Figure 5). Considering this fact, an incorrect judgement of time congruence would imply the failure of the corresponding agreement judgement every time. However, the high rate of correct decisions for agreement errors in the aphasic group shows just the opposite.

The other argument is based on a language theory consideration. According to recent syntactic theories (Chomsky 2000; 2001), tense and agreement are entities of entirely different status. Tense is an interpretable 


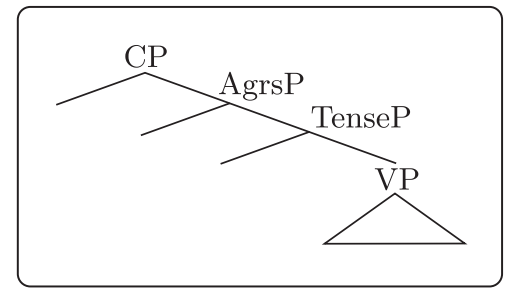

Fig. 5

The syntactic structure of the Hungarian sentence (based on Bartos 2000)

feature of the head of the TenseP, but agreement is an operation/relation. For that very reason the AgrP functional projection is not in the syntactic structure, but without this the TPH is unsuitable for the explanation of the selective deficit of tense.

We would not get nearer to a suitable explanation of our results if we tried to interpret the performance patterns in the framework of damaged/missing tense features. The problem is that if the underspecified tense feature is the only reason of the selective deficit of tense that has an effect on the processing of all sentences regardless of their grammaticality and word order, then how it is possible that the deficit affects the ungrammatical sentences in SAdvOV order and the grammatical sentences in SVOAdv order. Taking everything into consideration, it is more reasonable to suggest that the judgement of subject-verb agreement and time adverb-tense congruence is associated with two different processes on two distinct levels of sentence processing, as supposed by the syntax-discourse model (Avrutin 2006). Subject-verb agreement is a morphosyntacic process by which the semantically uninterpretable formal features of the verb are checked/evaluated (Chomsky 1995). Presumably, it is an intra-modular automatic process that operates at the narrow syntax level, thus requiring the least computation load as predicted by the economy hierarchy of structure building operations (Reuland 2001). The evaluation/checking of morphosyntactic features on narrow syntax is insufficient for the judgement of time incongruence. The correct interpretation of the time structure of a sentence requires various types of processes at different linguistic levels to integrate semantic time (expressed by a time adverb) and morphological time (marked by the verb tense). These processes are associated with operations on the information structure level, imposing the highest computation resources. The syntaxdiscourse theory in combination with the assumption that agrammatic 
aphasic patients have pathologically reduced resources available for language processing gives a suitable explanation for the dissociation between agreement and tense. We could say that the higher the computation need, the less successful the judgement of an incongruence. That is, the verification of agreement violation imposes fewer computation resources for sentence processing than tense violation does, so judgement of agreement can be intact in the aphasics examined.

Our second question was whether the position of the time adverb has an effect on the judgement of time incongruence. Since the aphasic participants were more sensitive to tense violation in the SAdvOV sentences than they were in the SVOAdv sentences, the answer is yes. Unfortunately, the economy hierarchy of structure building operations alone cannot explain this asymmetry. From the point of view of the economy hierarchy, there is no difference between sentences with pre- or post-verbal time adverbs. That is, the interpretation of time structure is connected to the information-structure level in both word orders. We showed that the aphasic participants made more false judgements in the ungrammatical SAdvOV sentences than in the grammatical ones. However, no grammaticality effect was found in sentences containing a post-verbal adverb. The different performance patterns suggest that the high rate of false decisions in the SAdvOV word order is in close connection with the processing of ungrammatical sentences.

Meng and Bader (2000) assume that the sentence processor treats ungrammatical sentences the same way as garden-path sentences. The characteristic feature of these sentences is that a transitional syntactic (or lexical) ambiguity appears at the point of processing. At this "disambiguation point" it becomes obvious that construction building so far cannot be continued any more (it would yield a structure which cannot be interpreted), so a reanalysis begins. The correct syntactic (or semantic) structure of the sentence is the result of this process. For example, in sentences containing morphological ambiguity involving possessive DPs - for which overt accusative marking is not obligatory in Hungarian (cf. (5) and (6) below) - , the parser may assign nominative case to the DP (lányom/ kutyám 'my daughter'/'my dog' before encountering the clause-final real subject (András/a kutya 'Andrew'/the dog'). At this "disambiguation point" it becomes evident that continuing the current syntactic analysis yields a semantically uninterpretable construction, since there are two distinct DPs with nominative case. From this point the parser reanalyses the sentence resulting in a syntactic structure in which the possessive DP 
(lányom/kutyám 'my daughter'/'my dog') is the object, and the sentence final DP (András/a kutya 'Andrew'/'the dog') is the only subject of the sentence.

$\begin{array}{llll} & \text { A lányom } & \text { elrabolta } & \text { András. } \\ & \text { my daughter-nom } & \text { kidnapped } & \text { Andrew-nom } \\ \text { first analysis: } & \mathrm{DP}_{\text {nom }} & \mathrm{V} & \mathrm{DP}_{\text {nom }} \\ \text { reanalysis: } & \mathrm{DP}_{\text {acc }} & \mathrm{V} & \mathrm{DP}_{\text {nom }}\end{array}$

(6)

$\begin{array}{llll} & \text { A macskám } & \text { kergette } & \text { a kutya. } \\ & \text { my cat-nom } & \text { chased } & \text { the dog-nom } \\ \text { first analysis: } & \mathrm{DP}_{\text {nom }} & \mathrm{V} & \mathrm{DP}_{\text {nom }} \\ \text { reanalysis: } & \mathrm{DP}_{\text {acc }} & \mathrm{V} & \mathrm{DP}_{\text {nom }} \\ & \text { 'The dog chased my cat.' } & \end{array}$

In the ungrammatical sentence, following Meng-Bader (2000), we suggest a reanalysis process similar to the one operating in garden-path sentences. It sets off as soon as the parser reaches the "disambiguation point" in the course of sentence processing. This point is the inflectional morpheme on the last constituent of the SAdvOV sentences:

(7) *Tegnap a lány a szobát kitakarítja.

yesterday the girl-nom the room-acc clean-3sg-present

'Yesterday the girl cleans the room.'

The reanalysis is considered to be a multipurpose reinterpretation process. One purpose is to decide if the sentence just heard is really ungrammatical or it was only misheard (Kolk-Chwilla 2007). Another purpose of the reanalysis is to look for some kind of interpretation to the expression. Perhaps both of them require reactivation of the phonological form of the sentence through the phonological loop. We hypothesize that, if reinterpretation is impossible due to the failure of phonological reactivation, the information necessary for the decision concerning the ungrammatical sentences is missing. In this case the sentence parser decides that there is time incongruence on the basis of information coming from non-linguistic context implying low computation resources.

The long reaction times in ungrammatical SAdvOV sentences in the aphasic participants (and control group) reflect the fact that the parser tries to reinterpret the time structure of the sentence. The high rate of incorrect decisions, however, suggests the failure of the reinterpretation. It 
is possible that decision is based on sentences containing an unreal time incongruence similar to examples (8a) and (8b), resulting in incorrect acceptance of ungrammatical sentence as grammatical.

(8) (a) Tegnap megyek az utcán és látom, hogy...

'Yesterday, I'm walking in the street and I can see that...'

(b) Holnap akartam meglátogatni Marit.

'I wanted to visit Mari tomorrow.'

In these sentences the adverbs specify the event times (tegnap/holnap 'yesterday'/'tomorrow'), thus the situations expressed by the sentences are interpreted within these time intervals (past/future) in spite of the fact that the tense morphemes denote different intervals. An argument against the idea that judgement is based on sentences like (8a) and (8b) might be that these sentences are used in a special register, and they are associated with a particular intonation contour. However, Broca's aphasics retain sensitivity to intonation (Avrutin et al. 1999).

Another possible account for aphasics' incorrect decisions for ungrammatical SAdvOV sentences might be that the patients are unable to perform phonological reactivation correctly due to slow activation (or fast decay) of the tense morpheme (Kolk 1995). Thus decisions are based on time adverbs without taking the tense morphemes into account, resulting in a high rate of false judgements. Unfortunately, at this point, we have no way of deciding between the two accounts. Further studies are required to test their role in grammaticality judgements.

We also propose that in the grammatical SAdvOV sentences there is no reanalysis. This might be the reason of above-chance performance and lower reaction times, in spite of the high computation load required for the interpretation of the time structure of sentences as predicted by the economy hierarchy of structure building operations. Taking everything into consideration, from the point of view of the economy hierarchy of structure building operations, reinterpretation is uneconomical and requires high computation resources that can overload the working memory in agrammatic aphasics.

Let us turn now to the sentences containing a post-verbal time adverb: SVOAdv sentences. The absence of a grammaticality effect here was unexpected, as the number of correct decisions was lower in grammatical sentences (containing yesterday/tomorrow) than in ungrammatical ones. Moreover, the mean reaction times of the grammatical and ungrammatical sentences were similar. These unusual patterns can result from the fact 
that the sequence of subject-verb-object preceding the adverb constitutes a complex syntactic structure, in the sense that the selection restriction of the verb is satisfied, and its morphosyntactic features are checked before the appearance of the adverb. The time structure of such an SVO sequence can also be interpreted because the event time is expressed by the tense morpheme.

There is a principle of the sentence parser that supports the earliest possible semantic interpretation of this structure. It is the "early closure principle", which says "a phrase is closed as soon as possible, unless the next node parsed is an immediate constituent of that phrase" (Kimball 1973). In an SVOAdv sentence the surface position of the time adverb is part of the VP, but semantically it is a sentence adverbial, so it relates to the whole proposition. On the other hand, the time adverb is not an argument of the verb, and more importantly, its surface position (end of the sentence) is unnatural in Hungarian. Relying upon these findings, we assume that, for the listener to be able to judge these sentences correctly, the sentence final time adverb needs to be integrated "post-hoc" into such an SVO structure. This interpretation process, however, involves both grammatical and ungrammatical sentences. Presumably, this is the reason why there are no significant differences between the mean reaction time of the grammatical and the ungrammatical sentences in this word order.

The pattern of correct decisions raises the possibility that judgements of these sentences were not based on such a "post-hoc" integration. As was mentioned earlier, the SVOAdv sentences pronounced with neutral intonation (identical stress on all content words) sound strange. The patients may have rejected these sentences purely because of their intonation patterns (and they did not analyse them semantically). In such cases, ungrammatical sentences may be accepted as grammatical, and grammatical sentences rejected as ungrammatical, resulting in the performance pattern shown above. Unfortunately, we cannot provide a satisfactory answer to the question of how "post-hoc" integration influences the working memory load. In order to get a clearer picture, we would need more systematic investigation with a larger sample of individuals with aphasia to find out if this type of reanalysis is a "difficult" or "easy" process (Gorell 1998; Friederici-Mecklinger 1996).

To conclude, the tense-agreement dissociation which has been found in many earlier studies (Friedmann-Grodzinsky 1997; 2000; WenzlaffClahsen 2004; 2005; Coltheart 2001; Burchert et al. 2005) can also be found in Hungarian agrammatic Broca's aphasics. Results from two ex- 
periments (off-line grammaticality judgements) indicated that the aphasic individuals we examined were more impaired on tense decisions, but word order and sentence grammaticality strongly influenced their performance. In judgements of time incongruence, a dissociation was found between sentences containing preverbal and postverbal time adverbs. However, our result was in contradiction with the results of Faroqi-ShahThompson (2007). Agreement-tense dissociation in Hungarian cannot be explained by a damaged syntactic representation (Friedmann-Grodzinsky 1997; Hagiwara 1995; Varlokosta et al. 2006). A theory based on a syntax-discourse model (Avrutin 2006) that takes the economy hierarchy of structure building processes into account is more suitable to account for selective deficit of tense. We "extended" this theory by considering the high memory load imposed by the reinterpretation process on the working memory during sentence processing. We regard the pathologically limited capacity of the working memory as the prime reason of the inability to judge particular ungrammatical sentences correctly.

\section{References}

Avrutin, Sergey 2006. Weak syntax. In: Katrin Amunts-Yosef Grodzinsky (eds): Broca's region, 49-62. Oxford University Press, Oxford.

Avrutin, Sergey - Stuart Lubarsky - Jennifer Greene 1999. Comprehension of contrastive stress by agrammatic Broca's aphasics. In: Brain and Language $70: 163-86$.

Bartos, Huba 2000. Az inflexiós jelenségek szintaktikai háttere [Syntactic background of inflectional phenomena]. In: Ferenc Kiefer (ed.): Strukturális magyar nyelvtan 3. Morfológia [A structural grammar of Hungarian 3. Morphology], 653-762. Akadémiai Kiadó, Budapest.

Burchert, Frank-Maria Swoboda-Moll-Ria De Bleser 2005. Tense and agreement in German agrammatic speakers: Underspecification vs. hierarchy. In: Brain and Language 94:88-199.

Chomsky, Noam 1995. The minimalist program. MIT Press, Cambridge MA.

Chomsky, Noam 2000. Minimalist inquiries: The framework. In: Roger Martin-David Michaels - Juan Uriagereka (eds): Step by step: Essays on minimalist syntax in honor of Howard Lasnik, 89-155. MIT Press, Cambridge MA.

Chomsky, Noam 2001. Derivation by phase. In: Michael Kenstowicz (ed.): Ken Hale: A life in language, 1-52. MIT Press, Cambridge MA.

Clahsen, Harald-Mohammad Ali 2009. Formal features in aphasia: Tense, agreement, and mood in English agrammatism. In: Journal of Neurolinguistics 22:436-50.

Coltheart, Max 2001. Assumptions and methods in cognitive neuropsychology. In: Brenda Rapp (ed.): The handbook of cognitive neuropsychology, 3-21. Psychology Press, Philadelphia.

Acta Linguistica Hungarica 58, 2011 
Comrie, Bernard 1985. Tense. Cambridge University Press, Cambridge.

Dickey, Michael Walsh-H. Lisa Milman-Cynthia K. Thompson 2005. Perception of functional morphology in agrammatic. Broca's aphasia. In: Brain and Language $95: 82-3$.

Faroqi-Shah, Yasmeen-Michael Walsh Dickey 2009. On-line processing of tense and temporality in agrammatic aphasia. In: Brain and Language 108:97-111.

Faroqi-Shah, Yasmeen - Cynthia K. Thompson 2007. Verb inflections in agrammatic aphasia: Encoding of tense features. In: Journal of Memory and Language 56 : $129-51$.

Friederici, Angela D. - Axel Mecklinger 1996. Syntactic parsing as revealed by brain responses: First-pass and second processes. In: Journal of Psycholinguistic Research $25: 157-76$.

Friedmann, Naama - Yosef Grodzinsky 1997. Tense and agreement in agrammatic production: Pruning in the syntactic tree. In: Brain and Language 56:397-425.

Friedmann, Naama-Yosef Grodzinsky 2000. Split inflection in neurolinguistics. In: Marc-Ariel Friedemann-Luigi Rizzi (eds): The acquisition of syntax, 84-104. Longman, Harlow.

Giorgi, Alessandra-Fabio Pianesi 1997. Tense and aspect: From semantics to morphosyntax. Oxford University Press, Oxford.

Gorell, Paul 1998. Syntactic analysis and reanalysis in sentence processing. In: Janet Dean Fodor - Fernanda Ferreira (eds): Reanalysis in sentence processing, 201-245. Kluwer, Dordrecht.

Hagiwara, Hiroko 1995. The breakdown of functional categories and the economy of derivation. In: Brain and Language 50:92-116.

Kimball, John 1973. Seven principles of surface structure parsing in natural language. In: Cognition $2: 15-7$.

Kolk, Herman 1995. A time-based approach to agrammatic production. In: Brain and Language $50: 282-303$.

Kolk, Herman-Dorothee Chwilla 2007. Late positivities in unusual situations. In: Brain and Language $100: 257-61$.

Levelt, Willem J. M. 1989. Speaking: From intention to articulation. MIT Press, Cambridge MA.

Linebarger, Marcia-Myrna Schwartz-Eleanor Saffran 1983. Sensitivity to grammatical structure in so-called agrammatic aphasics. In: Cognition 13:361-92.

Meng, Michael-Marcus Bader 2000. Ungrammaticality detection and garden path strength: Evidence for serial parsing. In: Language and Cognitive Processes 15 : 615-66.

Nanousi, Vicky- Jackie Masterson-Judit Drucks-Martin Atkinson 2006. Interpretable vs. uninterpretable features:Evidence from six Greek-speaking agrammatic patients. In: Journal of Neurolinguistics 19:209-38.

Osmanné Sági, Judit 1991. Az afázia diagnózisa és klasszifikációja [The diagnosis and classification of aphasia]. In: Ideggyógyászati Szemle 44:339-62.

Partee, Barbara H. 1973. Nominal and temporal anaphora. In: Linguistics and Philosophy $7: 243-86$. 
Reichenbach, Hans 1947. Elements of symbolic logic. Collier-Macmillan, London. Reuland, Eric J. 2001. Primitives of binding. In: Linguistic Inguiry 32:439-92.

Rice, Mabel L. - Kenneth Wexler - Sean M. Redmond 1999. Grammaticality judgments of an extended optional infinitive grammar: Evidence from English-speaking children with specific language impairment. In: Journal of Speech, Language, and Hearing Research $42: 943-61$.

Varlokosta, Spyridoula - Natalia Valeonti-Maria Kakavoulia-Mirto Lazaridou - Alexandra Economou - Athanassios Protopapas 2006. The breakdown of functional categories in Greek aphasia: Evidence from agreement, tense, and aspect. In: Aphasiology $20: 723-43$.

Wenzlaff, Michaela - Harald Clahsen 2004. Tense and agreement in German agrammatism. In: Brain and Language $89: 57-68$.

Wenzlaff, Michaela-Harald Clahsen 2005. Finiteness and verb-second in German agrammatism. In: Brain and Language 92:34-44.

\section{Appendix}

\begin{tabular}{|c|c|c|c|c|c|c|}
\hline & \multicolumn{3}{|c|}{ SOV word order } & \multicolumn{3}{|c|}{ VOS word order } \\
\hline & Gram. & Ungram. & $t$-test & Gram. & Ungram. & $t$-test \\
\hline VS & 498 & 423 & $t(19)=2.358, p<0.05$ & 450 & 586 & $t(19)=3.183, p<0.01$ \\
\hline ARI & 848 & 668 & $t(16)=6.367, p<0.001$ & 858 & 919 & $t(18)=0.631$, n.s. \\
\hline $\mathrm{VD}$ & 562 & 404 & $t(19)=3.441, p<0.01$ & 527 & 585 & $t(17)=0.463$, n.s. \\
\hline VJ & 639 & 507 & $t(19)=2.105, p<0.05$ & 590 & 699 & $t(19)=1.613$, n.s. \\
\hline $\mathrm{AM}$ & 404 & 347 & $t(19)=1.245$, n.s. & 321 & 503 & $t(19)=9.592, p<0.001$ \\
\hline OL & 429 & 412 & $t(19)=1.310$, n.s. & 400 & 493 & $t(19)=2.379, p<0.05$ \\
\hline PM & 520 & 546 & $t(19)=0.481$, n.s. & 499 & 654 & $t(18)=2.229, p<0.05$ \\
\hline SH & 398 & 318 & $t(19)=1.496$, n.s. & 252 & 499 & $t(15)=5.419, p<0.001$ \\
\hline BZS & 793 & 648 & $t(19)=1.370$, n.s. & 770 & 879 & $t(19)=0.920$, n.s. \\
\hline
\end{tabular}

Individual patterns of mean reaction times of control participants 